\title{
Evaluation of the Results of Antiviral Therapy in Pregnant Women with Chronic Hepatitis $B$
}

Kronik Hepatit B'li Gebelerde Uygulanan Antiviral Tedavi Sonuçlarının Değerlendirimesi

\author{
Ayşe ERTÜRK1, Ekan CÜRE2, Emine PARLAK3, Medine Cumhur CÜRE4, Ayşegül ÇOPUR ÇiÇEK5, \\ Figen KIR ŞAHIN6 \\ 1 Recep Tayyip Erdoğan University Faculty of Medicine, Department of Infectious Diseases, Rize, Turkey \\ ${ }^{2}$ Recep Tayyip Erdoğan University Faculty of Medicine, Department of Internal Medicine, Rize, Turkey \\ ${ }^{3}$ Atatürk University Faculty of Medicine Department of Infectious Diseases, Erzurum, Turkey \\ 4Recep Tayyip Erdoğan University Faculty of Medicine, Department of Biochemistry, Rize, Turkey \\ 5 Recep Tayyip Erdoğan University Faculty of Medicine, Department of Clinical Microbiology, Rize, Turkey \\ ${ }^{6}$ Recep Tayyip Erdoğan University Faculty Of Medicine, Department of Obstetrics and Gynecology, Rize, Turkey
}

\section{ABSTRACT}

Objective: Perinatal transmission is one of the most common transmission routes of hepatitis B virus (HBV) disease. It is possible to prevent transmission with antiviral treatment performed in pregnant women with high viral load in adition to the passive and active immunization treatment performed in the infant. The aim of this study was to investigate the safety of antiviral treatment during pregnancy and its effects on the seroconvertion of Hepatitis B in pregnant and newborn.

Materials and Methods: The effects of antiviral treatment (lamivudine, tenofovir, telbivudine) performed in 17 pregnant women who were admitted to the infectious disease outpatient clinic of our hospital between years 2011-2013 and who had chronic hepatitis $\mathrm{B}(\mathrm{CHB})$ and a high viral load on the mother andt the newborn were evaluated retrospectively.

Results: Following 8-12 weeks of antiviral treatment, HBV-DNA levels were decreased to $\leq 10.000 \mathrm{IU} / \mathrm{mL}$ in the $11 / 17(64.7 \%)$ patients, there were $>2 \log 10$ (IU / $\mathrm{mL}$ ) of reduction in average, liver enzymes were decreased in 15/17 (88.2\%) patients. There were no observed drug side effects and complications in mother and newborn.

Conclusion: After the antiviral therapy viral load decreased in HBsAg positive pregnant women and perinatal transmission is prevented, thus, this supported the aim of "obtaining HBV seroconversion only with immunization". (Viral Hepatitis Journal 2014; 20(1): 23-27)

Key words: Pregnancy, chronic hepatitis B, antiviral treatment
ÖZET

Amaç: Perinatal geçiş, hepatit B virüs (HBV) hastalı̆ı̆ın en sık bulaşma yollarından biridir. Bu geçişi önlemek, bebeğe uygulanan pasif ve aktif immünizasyona ek olarak yüksek viral yükü olan gebeye uygulanan antiviral tedaviler ile mümkündür. Gebelik sırasında antiviral tedavinin güvenilirliğini ve gebe ile çocukta Hepatit B serokonversiyonu üzerine etkilerini araştırmayı amaçladık.

Gereç ve Yöntemler: Kronik hepatit B (KHB)'li viral yükü yüksek gebelerden 20112013 yılları arasında hastanemiz enfeksiyon hastalıkları polikliniğine başvuran 17 hastaya uygulanan antiviral tedavilerin (lamivudin, telbivudin, tenofovir) anne ve çocuk üzerindeki sonuçları retrospektif olarak değerlendirildi.

Bulgular: KHB'li gebelerde HBV-DNA seviyelerinin 8-12 haftalık antiviral tedaviyi takiben $11 / 17(\% 64,7)$ hastada $\leq 10000 \mathrm{IU} / \mathrm{mL}$ seviyelerine gerilediği ortalama $>2 \log 10$ (IU/mL) azalma olduğu, hastaların 15/17 (\%88,2)'sinde karaciğer enzimlerinin gerilediği, anne ve çocukta ilaç yan etki ve komplikasyonlarının gelişmediği gözlendi.

Sonuç: HBsAg'si pozitif gebelerde antiviral tedavi sonrası viral yük azalmakta, perinatal geçiş engellenmekte, bu sayede "sadece immunizasyon ile HBV serokonversiyonu elde etme" amacı desteklenmektedir. (Viral Hepatit Dergisi 2014; 20(1): 23-27)

Anahtar Kelimeler: Gebelik, kronik hepatit B, antiviral tedavi 


\section{Introduction}

Perinatal transmission is the most seen contamination way of the hepatitis B virus (HBV) on all the world $(1,2)$. Despite the immunisation, newborn children who infected with HBV is associated with high viremia levels of his or her mother. For this reason, to prevent the transmission of HBV in perinatal period, vaccine and passive immunisation treatments applied on the last trimester were added to the treatment protocols.

Antiviral treatments applied on during pregnancy has always been arguable because of its discontinuation due to its adverse effects and as a result, an increased hepatic exacerbation risk and probability of development of resistance. The preliminary results from ongoing studies are likely to be supportive the chronic hepatitis $B$ virus $(\mathrm{CHBV})$ infection in pregnants. $(3,4)$. Antiviral treatments are commonly applied (because of there will be any complication or to slow or stop the progression of mother's liver disease) on the last trimester to decrease of both the contamination risk of HBV to the fetus and the treatment of the chronical hepatitis $B$ infection in the pregnant. Moreover the treatment are recommended even earlier period in pregnant with severe liver disease and has a decompansation risk. In conclusion, the treatment of pregnants needs on the basis of individual assessment $(3,4)$.

In this study, we evaluated if any complication occurs during the $\mathrm{CHBV}$ treatment applied on the last trimester in both pregnant and child, the effect of antiviral treatment on hepatitis B seroconversion in pregnant and children as well.

\section{Material and Methods}

In this retrospective study, the pregnants were included who diagnosed with $\mathrm{CHBV}$ infection and treated with antiviral treatment in their last trimester period by Obstetric and Gynecology with Infectious Diseases Department of Recep Tayyip Erdogan University Medical Faculty, from 1 January 2011 to 30 July 2013. Any chronical diseases, regularly medicine intake, alcohol or cigarette use history were excluded. The pregnants who are inactive HBV carriers were not included.

All pregnants' liver enzymes were monitored. Biochemical parametres were analysed using by Abbott Laboratories Architect C16000 analyzer (Abbott Laboratories). All pregnants' hepatitis B surface antigen ( $\mathrm{HBsAg})$, anti-HBs, hepatitis $\mathrm{B}$ e antigen ( $\mathrm{HBeAg})$ and anti-HBe and co-infections' serologies like that of HIV, HCV and HDV were determined using by Enzyme Linked Immunosorbend Assay (ELISA) (Abbott Architect, USA) method.

HBV-DNA analysis were carried out by PCR method in Cobas Taqman 48 analyser (Roche) and results were stated as $1 \mathrm{IU} /$ $\mathrm{mL}=5.82 \mathrm{copy} / \mathrm{mL}$. A linear distribution (the minimum detection limit of HBV-DNA was $6 \mathrm{IU} / \mathrm{mL}=35 \mathrm{copy} / \mathrm{mL}$ and maximum of it was $1.1 \times 109 \mathrm{IU} / \mathrm{mL}=6.4 \times 109 \mathrm{copy} / \mathrm{mL}$ ) was applied for analysis. Results which exceeds the upper limit was measured again after 100.000 times diluted of HBV-DNA. "Primary non-response" was defined as a lesser decline of serum HBV-DNA levels than $<1$ $\log 10$ (100 times) at the 12.weeks or $<2 \log 10$ (100 times) at the 24.weeks than that of baseline. "Virological progress" was determined for patients giving antiviral treatment as "an > $1 \log 10$ (10 times) $\mathrm{IU} / \mathrm{mL}$ increase" or for patients whose HBV-DNA is negative (HBV DNA $<2.000 \mathrm{IU} / \mathrm{mL}=<104$ copy/mL) as "their serum HBV-DNA is now positive". Antiviral resistance testing and viral mutation analyses of these patients were carried out using by a line prob analysis [LiPA, (Innogenetics NV, Gent, Belgium)]. The patients' biochemical, virological or serological results were recorded until the end of the delivery week and in the first year of the delivery. So this patients' data were reviewed retrospectively and these parameters were analysed.

\section{Results}

Patients had no treatment history for the first two trimester of their pregnancy. In history, only one patient had a "interferone" treatment, two of patients had a "lamivudine" treatment, and one patient had a "tenofir treatment after lamivudine medication" in their past. Over pregnancy following, two of patients' viral charges (>106-9 IU/mL) and alanine aminotransferase (ALT) levels have fluctuated during the first two trimester. Treatment have been started to the CHBV infection patients whose HBV-DNA levels $>105 \mathrm{lU} / \mathrm{mL}$ in their 28 to 32. gestational weeks. Lamivudine treatment (100 mg per day) was started to 9 of patients, telbivudine was started to 7 of patients and tenofovir medication was started to one patient.

Mean age of pregnants was $28.2 \pm 5.4$ years of age (21-39 years). There was HBeAg positivity in 6/17 of patients (35.3\%). Mean serum ALT levels in the pretreatment measures was $57.7 \pm 63.2$ IU/L (13-277 IU/L). Liver enzymes levels were regressed in 15/17 of patients (88.2\%) and mean level of it was 34.5 $\pm 26.9 \mathrm{IU} / \mathrm{L}(9-96$ IU/L). Mean HBV-DNA levels at first were $3.3 \pm 2.1 \times 106.5 \pm 1.3$ $\mathrm{IU} / \mathrm{mL}$. At delivery week, mean HBV-DNA level was found as $3.0 \pm 2.2 \times 10^{3}, 1 \pm 2.3 \mathrm{IU} / \mathrm{mL}$. Approximately after a 8-to- 12 weeks treatment period, roughly mean decline of $>2 \log 10(\mathrm{IU} / \mathrm{mL})$ and a regression to $\leq 10000 \mathrm{IU} / \mathrm{mL}$ levels in $11 / 17$ of patients $(64.7 \%)$ were detected (see Table 1).

One patient was resistant to the lamivudine treatment at the beginning of the treatment (at the 30th gestational weeks), so she was treated by tenofovir as she used to. Adverse reactions or complications were monitored for all mothers and their babies. $\mathrm{HbsAg}$ transmission were not detected in the babies at their birth or following periods and all of children were anti-HBs positive with immunisation. In two patients who treated by lamivudine during their pregnancy period were detected the lamivudine resistance and one of them was given entacavir, and another was treated by tenofovir. HBeAg loss was not found any of all patients and ALT normalisation ratio was high (88.2\%). HBV-DNA negativity was found as $17.6 \%$ of patients (see Table 2).

Virological progress with an HBV-DNA >2log10 increase was found in 11 of patients whose treatment was discontinued within the first year. So, lamivudine treatment was started to seven of these patients, tenofovir was began to two patients, one of patients was treated with telbivudine and another was treated by entacavir. Virological supress (HBV-DNA negativity at the 1st year) was achieved in six of eight patients who treated by telbivudine, and their follow-up was continued (see Table 3).

\section{Discussion}

Throughout the world, 240 million people have been infected by HBV and every year round 600000 of them dies because of its acute or chronic (5). According to the World Health Organisation (WHO) the prevalence of HBV is seen by far the most in SubSahara Africa and East Asia, and in these regions persons have 


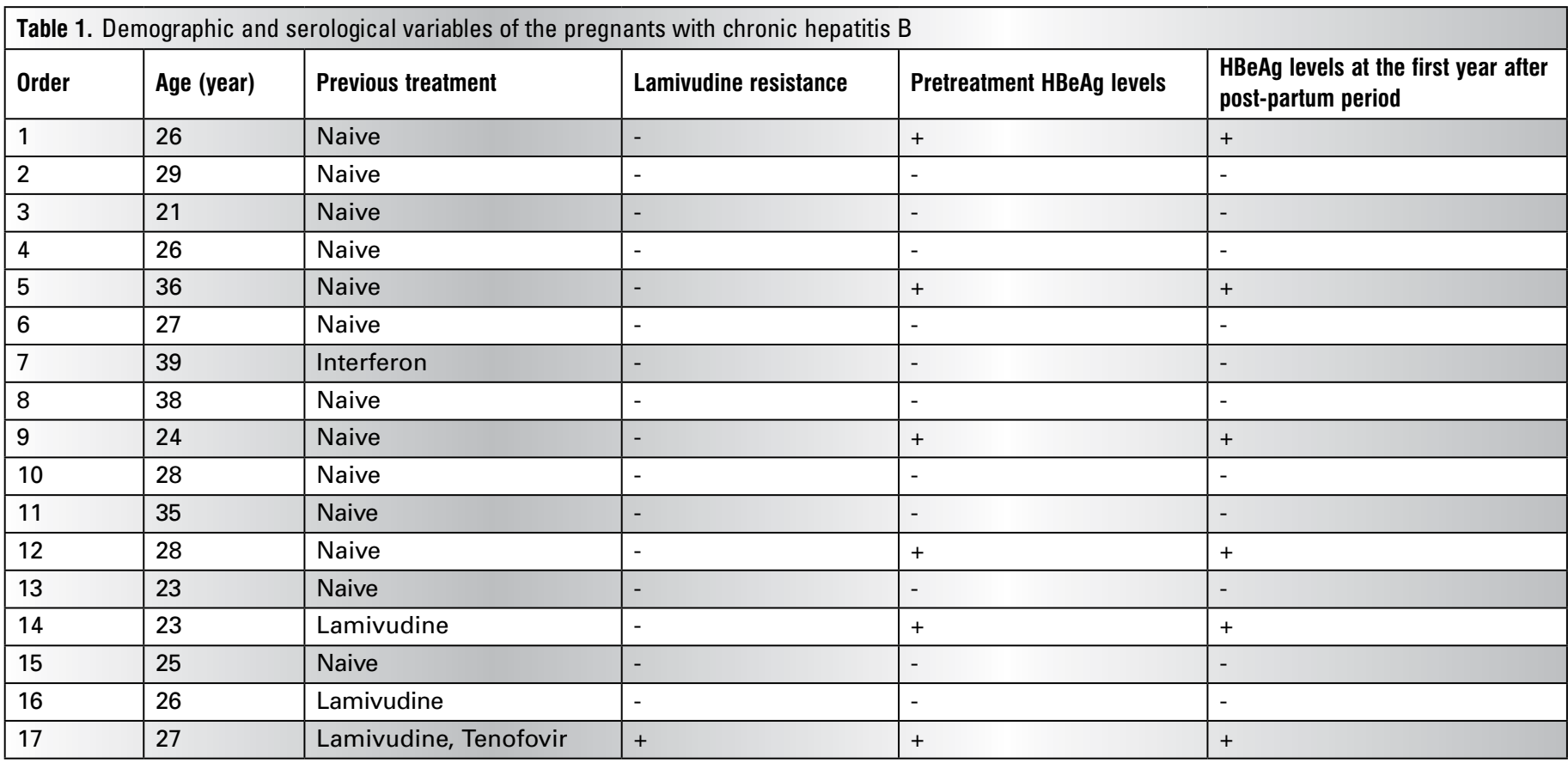

Table 2. Biochemical parametres of pre- and post-treatment periods of pregnants with chronic hepatitis B infection

\begin{tabular}{|c|c|c|c|c|}
\hline Order & $28^{\text {th }}$ to $32^{\text {th }}$ gestational weeks ALT (IU/L) & $\begin{array}{l}\text { Treatment applied for in the last } \\
\text { trimester }\end{array}$ & \begin{tabular}{|l|} 
Post-partum \\
ALT(IU/L)
\end{tabular} & $\begin{array}{l}\text { ALT(IU/L)at the first year after } \\
\text { post-partum period }\end{array}$ \\
\hline 1 & 54 & Telbivudine & 27 & 35 \\
\hline 2 & 35 & Telbivudine & 33 & 118 \\
\hline 3 & 25 & Telbivudine & 23 & 47 \\
\hline 4 & 28 & Telbivudine & 13 & 23 \\
\hline 5 & 13 & Telbivudine & 11 & 21 \\
\hline 6 & 36 & Telbivudine & 29 & 38 \\
\hline 7 & 36 & Telbivudine & 17 & 15 \\
\hline 8 & 64 & Telbivudine & 92 & 43 \\
\hline 9 & 277 & Lamivudine & 60 & 17 \\
\hline 10 & 66 & Lamivudine & 17 & 28 \\
\hline 11 & 57 & Lamivudine & 46 & 27 \\
\hline 12 & 105 & Lamivudine & 56 & 41 \\
\hline 13 & 13 & Lamivudine & 9 & 24 \\
\hline 14 & 24 & Lamivudine & 17 & 15 \\
\hline 15 & 20 & Lamivudine & 23 & 19 \\
\hline 16 & 23 & Lamivudine & 17 & 21 \\
\hline 17 & 106 & Tenofovir & 96 & 93 \\
\hline
\end{tabular}

infected with it during their childhood period $(5,6)$. Turkey, on the other hand, is one of the medium-endemic regions with $2 \%-7 \%$ as regards HBsAg carrying. Different studies related the prevalence of $\mathrm{HBV}$ is roughly at similar rates. Ergunay et al., for instance, reported that the anti-HBs seroprevalence was $43.4 \%$ and $\mathrm{HBsAg}$ seroprevalence was 6\% between 2000 and 2010 years. From 1998 onwards all newborns are rutinely vaccinated with Hepatitis B vaccine at extended immunisation programme (EIP)'s behest. Even though this programme were elaborately applied, seroprevalence of HBsAg just only regressed from $12.3 \%$ to $5 \%$ in this decade (2000-2010 years) (7).
In studies carried out in pregnants (from minimum more than 3.000 to maximum 90000 of samples), however, HBsAg positivity rates were found from $1.9 \%$ to $3.5 \%$ (mean of $3 \%$ ) $(8,9)$. In a study, conducted in Rize province's pregnants, HBsAg seropositivity rates were found $5.7 \%$ amongst the 5894 of pregnants, and anti-HBs seroprevalence was reported in 5376 pregnants as $29.7 \%$ (10).

Infection can mostly transmit perinatal or horisontal ways in the high prevalence regions. CHBV infection progression risk is negatively correlated with age that it trasmitted. Transmission of infection to babies from their $\mathrm{HBeAg}$ positive mother occurs up to $90 \%$ rates without immunprophylaxis whereas it is $10 \%-40 \%$ 


\begin{tabular}{|c|c|c|c|c|c|}
\hline Order & $\begin{array}{l}2^{28-32^{\text {th }}} \text { gestastional weeks } \\
\text { HBV-DNA (IU/mL) }\end{array}$ & \begin{tabular}{|l|} 
Treatment applied in \\
the last trimester period
\end{tabular} & $\begin{array}{l}\text { Post-partum HBV-DNA } \\
(\mathrm{IU} / \mathrm{mL})\end{array}$ & $\begin{array}{l}\text { Post-partum at } 1^{\text {st }} \text { year } \\
\text { HBV -DNA (IU/mL) }\end{array}$ & $\begin{array}{l}\text { Post-partum } 1^{\text {st }} \text { year } \\
\text { treatment option }\end{array}$ \\
\hline 1 & $1.1 \times 10^{9}$ & Telbivudine & $3.4 \times 10^{6}$ & $1.5 \times 10^{8}$ & Tenofovir \\
\hline 3 & $2.3 \times 10^{6}$ & Telbivudine & $5.1 \times 10^{4}$ & Negative & - \\
\hline 4 & $3.2 \times 10^{7}$ & Telbivudine & $4.3 \times 10^{4}$ & Negative & - \\
\hline 5 & $1.9 \times 10^{5}$ & Telbivudine & $1.4 \times 10^{4}$ & Negative & - \\
\hline 7 & $1.3 \times 10^{6}$ & \begin{tabular}{|l|} 
Telbivudine \\
\end{tabular} & $4.5 \times 10^{4}$ & Negative & - \\
\hline 8 & $3.8 \times 10^{6}$ & Telbivudine & Negative & Negative & - \\
\hline 9 & $6.2 \times 10^{9}$ & \begin{tabular}{|l|} 
Lamivudine \\
\end{tabular} & $8.9 \times 10^{6}$ & $3.2 \times 10^{5}$ & Lamivudine \\
\hline 10 & $6.0 \times 10^{5}$ & Lamivudine & $3.6 \times 10^{4}$ & $3.4 \times 10^{5}$ & Lamivudine \\
\hline 11 & $1.4 \times 10^{6}$ & Lamivudine & $4.5 \times 10^{5}$ & $2.1 \times 10^{6}$ & Lamivudine \\
\hline 12 & $5.1 \times 10^{8}$ & Lamivudine & $1.3 \times 10^{6}$ & $1.0 \times 10^{6}$ & Lamivudine \\
\hline 16 & $3.1 \times 10^{6}$ & Lamivudine & \begin{tabular}{|l|} 
Negative \\
\end{tabular} & $9.9 \times 10^{5}$ & Lamivudine \\
\hline 17 & \begin{tabular}{|l|}
$1.2 \times 10^{6}$ \\
\end{tabular} & Tenofovir & $2.8 \times 10^{4}$ & $2.1 \times 10^{8}$ & Tenofovir \\
\hline
\end{tabular}

if there is $\mathrm{HBeAg}$ negative mother. In children aged 1 to 5 , the contamination rate is $20 \%-30 \%$ whilest it is less $5 \%$ in adults. Thus, the presence of HBV infection continues as an important source of perinatal $\mathrm{CHBV}$ infection. If hepatitis $\mathrm{B}$ immunglobuline (HBIG) is applied to the baby who her or his mother is HBeAg positive immediately after delivery, the contamination risk falls to $5 \%-10 \%$. Therefore, HBIG application is crucial for decreasing the fulminant hepatitis risk in infants and the contamination from $\mathrm{HBeAg}$ negative mother $(11,12)$. However, $5 \%$ of infants can be contaminated by HBV transmission although both active and passive immunisation and even in $8 \%-10 \%$ of newborns whose HBeAg positive (serum HBV-DNA >106-7 IU/mL) mothers could develop CHBV infection. This situation has been correlated with mother's high HBV viral charge $(13,14,15)$. During pregnancy, antiviral treatment in which applied for the last trimester has been suggested that it could decrease the vertical transmission. Regions in which HBV infections are endemic, lamivudine treatment applied for in the last trimester has been reported as effectively protector $(16,17)$. Consequently, in pregnant who has HBV infection and viral charge is high (HBVDNA >106 IU/mL), antiviral treatment should be given in 28-32nd gestational weeks. Lamivudine and entecavir are two medication in which located $\mathrm{C}$ category for pregnant security in Food and Drug Administration (FDA) list, whereas tenofovir and telbivudine are located in B category for security of pregnants. Lamivudine and tenofovir are highly favourable to treatment because their safety studies in pregnants have been carried $(18,19)$.

In general population, the aims of treatment are the following: to develop HBV-DNA negativity, permanent virological responce (HBVDNA $<2000 \mathrm{lU} / \mathrm{mL}=<104 \mathrm{copy} / \mathrm{mL}$ ) and $\mathrm{HBeAg}$ seroconversion, (if any) HBsAg loss (and/or anti-HBs seroconversion). In addition to these, in pregnancy, to prevent from transmission without developing any complication in both mother and baby. Oral antivirals like tenofovir, entecavir, telbivudine and lamivudine are effective and rarely unresponsive agents (19).

Data related to lamivudine, tenofovir and telbivudine use in pregnants with $\mathrm{CHBV}$ has been cumulated in the last decade
$(15,17,20)$. In a meta-analysis, conducted by Han et al., lamivudine treatment applied to the pregnants with CHBV infection and have high viremia charge in $28^{\text {th }}$ gestational weeks was found that it has decreased the viremia charge up to $<10^{6} \mathrm{copy} / \mathrm{mL}$, as very effective for stopping to transmission it from mother to baby even more than that of HBIG (21). Another studies have supported this conclusion $(17,22)$. Recent studies has been reported that telbivudine did not any adverse effect on mothers, there were no found any anomalies in their babies, viral charge has been supressed and HBsAg transmission was blocked by it $(20,23,24)$. Another aspect, recently reported studies have been argued that tenofovir, highly potent and safer ajent, recommended for use in pregnancy who have high viremia charge with $\mathrm{HBeAg}$ positive (15). Kose et al., limavudine treatment has been found as effective as a decrease of $71 \%$ rate of HBV-DNA and in infants seropositivity of HBsAg occuring after transfusion has been blocked by (2). In our study, a regression to $\leq 10000 \mathrm{IU} / \mathrm{mL}$ levels in $64.7 \%$ of patients and there was a mean of $>2 \log _{10}(\mathrm{IU} / \mathrm{mL})$ decline after $8-12^{\text {th }}$ weeks antiviral treatment were detected.

There were found birth defects with lamivudine and tenofovir treatment using in the first trimester of pregnancy, $2.9 \%$ and $2.4 \%$, respectively. Telbivudine treatment was shown as safe for anomalies as Liu et al., shown in their study (23). Compared to previous studies birh anomalies rates are the following: 5.1\%$6.3 \%$ for babies born from mothers who have no HBV infection, 7.2\%-10\% for babies born from mothers with HBV infection, if telbuvidine treatment were applied to pregnants either in prepregnancy or during pregnancy periods, in this case it was only $3.8 \%$ rates $(3,20)$. In our study, there were neither any adverse effects nor any complications detected in treated mothers and their children. Babies have no HBsAg at the birth and the following periods and all have anti-HBs positivity.

In pregnancy period HBV infections' activation can be seen and if they have not treated, or their anti-HBV treatment have been discontinued during pregnancy or after delivery for any reason, it could cause a hepatic exacerbation. These patients need a closely follow-up $(3,25)$. Recent study, lamivudine resistance was occured 
in two patients, who treated in their pregnancy periods, at the end of the first year. In this duration, one patient was treated by entacavir, and another treated by tenofovir, and followed. There were no $\mathrm{HBeAg}$ loss and there were ALT normalisation and HBV-DNA negativity. Compared to the lamivudin, in six out of eight patients treated with telbivudine were detected a virological supress (HBVDNA negativity) continuing the first year after delivery. This result can be contributed with that there is HBV mutants strains in their environments, and high lamivudine resistance rates stemming from its use for more than 5 years (19).

Results of this study show that antiviral treatment applied in the last trimester to pregnants is safe and tolerable for both mothers and their children. During pregnancy and perinatal periods there is no increased adverse effect and it could continue to have advantage of preventive effect from complications. After antiviral treatment viral charge is lesser in pregnants with HBsAg positive, perinatal transmission is blocked, and HBV seroconversion -which obtained in children only with vaccines and HBIG immunisation- is achieved by. There were no any anomalies detected in the infants. As a result, antiviral treatments' benefits are higher. In case of discontinuation of antiviral treatments after delivery, hepatic exacerbasion can occur and for this process, there is a need for futher studies evaluating and optimising the procedures.

\section{Conclusion}

In pregnants, antiviral treatment applied in the last trimester is safe for both mothers and their babies. Antiviral treatment given the pregnancy periods declines the risk of contamination of $\mathrm{HBV}$ infection to newborns.

\section{Conflict of interest: None declared.}

\section{References}

1. Tran TT. Management of hepatitis B in pregnancy: Weighing the options. Cleveland Clin J Med. 2009; 76(Suppl 3): 25-29.

2. Köse Ş, Türken M, Devrim I, Taner C. Efficacy and safety of lamivudine treatment in late pregnancy with high HBV DNA: a perspective for mother and infants. J Infect Dev Ctries. 2011; 5: 303-306.

3. Bzowej NH. Optimal Management of the hepatitis B patient who desires pregnancy or is pregnant. Curr Hepatitis Rep. 2012; 11: 82-89.

4. Natalie H. Bzowej. Hepatitis B therapy in pregnancy. Curr Hepatitis Rep. 2010; 9: 197-204.

5. World Health Organization. Hepatitis B. World Health Organization fact sheet $\mathrm{N}^{\circ} 204$ updated July 2013. Available at http://www.who.int/mediacentre/factsheets/fs204/en/

6. Al-Naamani K, Al-Maqbali A, Al-Sinani S. Characteristics of hepatitis B infection in a sample of Omani patients. Sultan Qaboos Univ Med J. 2013; 13: 380-385.

7. Ergunay K, Balaban $Y$, Cosgun E, Alp A, Simsek H, Sener B, Tatar G, Hascelik G. Ann Epidemiologic trends in HBV infections at a reference centre in Turkey: an 11-year retrospective analysis. Ann Hepatol. 2012; 11: 672-678.

8. Karlıdağ GE. Elazığ kent merkezinde Bir hastaneye başvuran gebelerde HBsAg seroprevalansı. FÜ Sağ Bil Tıp Derg. 2011; 25: 111-113.
9. Çiçek AÇ, Duygu F, Inakçı IH. Şanlıurfa ilinde Kadın Hastalıkları ve Doğum Hastanesine başvuran kadınlarda hepatit $B$ ve hepatit C seroprevalansı: Üç yıllık değerlendirme. Viral Hepatit Dergisi. 2012; 18: 15-18.

10. Balık G, Ü Işık, Kağıtcı M. Rize bölgesinde yaşayan gebe kadınlarda HBsAg, antiHBs ve anti-HCV seroprevalansı. Dicle Tip Dergisi. 2013; 40: 254-257.

11. Chen HL1, Lin LH, Hu FC, Lee JT, Lin WT, Yang YJ, Huang FC, Wu SF, Chen SC, Wen WH, Chu CH, Ni YH, Hsu HY, Tsai PL, Chiang $\mathrm{CL}$, Shyu MK, Lee Pl, Chang FY, Chang MH. Effects of maternal screening and universal immunization to prevent mother-to-infant transmission of HBV. Gastroenterology. 2012; 142: 773-781.

12. Chang KM. Hepatitis B immunology for clinicians. Clin Liver Dis. 2010; 14: 409-424.

13. Centers for Disease Control and Prevention. Disease burden from hepatitis A, B and C; 2011. Available at:http://www.cdc. gov/hepatitis/Statistics/index.htm

14. Nayeri UA, Werner EF, Han CS, Pettker CM, Funai EF, Thung SF. Antenatal lamivudine to reduce perinatal hepatitis $B$ transmission: a cost-effectiveness analysis. Am $\mathrm{J}$ Obstet Gynecol. 2012; 207: 231.e1-7.

15. Pan CQ1, Mi LJ, Bunchorntavakul C, Karsdon J, Huang WM, Singhvi G, Ghany MG, Reddy KR. Ttenofovir disoproxil fumarate for prevention of vertical transmission of hepatitis $B$ virus Infection by highly viremic pregnant women: a case series. Dig Dis Sci. 2012; 57: 2423-2429.

16. Xu XW and Chen YG. Current therapy with nucleoside/ nucleotide analogs for patients with chronic hepatitis $B$. Hepatobiliary Pancreat Dis Int. 2006; 5: 350-359.

17. Xu WM, Cui YT, Wang L, Yang $H$, Liang ZQ, Li XM, Zhang SL, Qiao FY, Campbell F, Chang CN, Gardner S, Atkins M. Lamivudine in late pregnancy to prevent perinatal transmission of hepatitis B virus infection: a multicentre, randomized, double-blind, placebo-controlled study. J Viral Hepat. 2009; 16: 94-103.

18. Lee, NM, Brady C W. Liver disease in pregnancy. World J Gastroenterol. 2009; 15: 897-906.

19. European Association For The Study Of The Liver. EASL Clinical Practice Guidelines:Management of chronic hepatitis B. J Hepatol. 2009; 50: 227-242.

20. Han GR1, Cao MK, Zhao W, Jiang HX, Wang CM, Bai SF, Yue $X$, Wang GJ, Tang $X$, Fang ZX. A prospective and open-label study for the efficacy and safety of telbivudine in pregnancy for the prevention of perinatal transmission of hepatitis $B$ virus infection. J Hepatol. 2011; 55: 1215-1221.

21. Han L, Zhang HW, Xie JX, Zhang Q, Wang HY, Cao GW. A meta-analysis of lamivudine for interruption of mother-to-child transmission of hepatitis B virus. World J Gastroenterol. 2011; 17: 4321-4333.

22. van Zonneveld $M$, van Nunen $A B$, Niesters $H G$, de Man RA, Schalm SW, Janssen HL. Lamivudine treatment during pregnancy to prevent perinatal transmission of hepatitis $B$ virus infection. J Viral Hepat. 2003; 10: 294-297.

23. Liu M, Cai H, Yi W. Safety of telbivudine treatment for chronic hepatitis B for the entire pregnancy. J Viral Hepat. 2013; 20(Suppl 1): 65-70

24. Pan CQ1, Han GR, Jiang HX, Zhao W, Cao MK, Wang CM, Yue $X$, Wang GJ. Telbivudine prevents vertical transmission from $\mathrm{HBeAg}$-Positive women with chronic hepatitis B. Clin Gastroenterol Hepatol. 2012; 10: 520-526.

25. ter Borg MJ, Leemans WF, de Man RA, Janssen HL. Exacerbation of chronic hepatitis B infection after delivery. J Viral Hepat. 2008; 15: 37-41. 